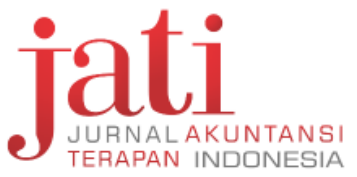

Jati: Jurnal Akuntansi Terapan Indonesia Vol 2 No 2 Hal 41-47 Oktober 2019

\section{Analisis Pendayagunaan Zakat Produktif Dalam Peningkatan Pendapatan Mustahik Melalui Program Bangkit Usaha Mandiri Sukabumi (BUMI)}

http://journal.umy.ac.id/index.php/jati DOI: 10.18196/jati.020216

DATA ARTIKEL:

Diterima: 26 Juli 2019

Direviu: 16 September 2019

Direvisi: 16 Oktober 2019

Disetujui: 31 Oktober 2019

\section{TOPIK ARTIKEL:}

Akuntansi Sektor Publik, Akuntansi Syariah

ABSTRAK: Penelitian ini bertujuan untuk mengetahui bagaimana pendayagunaan zakat produktif melalui program Bangkit Usaha Mandiri Sukabumi yang dilakukan oleh Badan Amil Zakat Nasional Kabupaten Sukabumi dalam peningkatan pendapatan mustahik. Penelitian ini menggunakan metode deskriptif dengan pendekatan kualitatif. Penulis melakukan teknik pengumpulan data melalui wawancara, dokumentasi, dan observasi. Pengolahan data dengan cara deskriptif analisis yaitu suatu teknis penulisan dengan memaparkan semua data yang diperoleh melalui wawancara, dokumentasi, dan bahan pustaka dan menganalisisnya dengan berpedoman sumber tertulis. Dari hasil penelitian ini menunjukkan bahwa Badan Amil Zakat Nasional Kabupaten Sukabumi melakukan penyaluran dan pendayagunaan dana ZIS dengan membuat programprogram pemberdayaan masyarakat. Program Bangkit Usaha Mandiri Sukabumi sudah berjalan efektif, terbukti dengan tercapainya tujuan dari program tersebut yaitu untuk kesejahteraan masyarakat, peningkatan pendapatan mustahik, dan peningkatan dari segi sosial dan keagamaan.

Kata Kunci: Zakat Produktif, Pendapatan, Pendayagunaan Zakat

ABSTRACT: This research aims to determine how the utilization of productive zakat through the
Bangkit Usaha Mandiri Sukabumi Program conducted by the National Amil Zakat Agency in Sukabumi Regency in increasing mustahik income. This research uses descriptive method with a qualitative approach. The author uses data collection techniques through interviews, documentation, and observation. Data processing by means of descriptive analysis is a technical writing by describing all data obtained through interviews, documentation, and library materials and analyzing it by using written sources. The results of this study indicate that the National Amil Zakat Board of Sukabumi Regency distributes and utilizes ZIS funds by making community empowerment programs. Bangkit Usaha Mandiri Sukabumi Program has been running effectively, as evidenced by the achievement of the objectives of the program, namely for the welfare of the community, increasing income mustahik, and improving in terms of social and religious.

\section{Keywords: Productive Zakat, Income, Zakat Utilization}

\section{SITASI ARTIKEL:}

Muzdalifah, N.N., Sulaeman \& Kartini, T. (2019). Analisis Pendayagunaan Zakat Produktif Dalam Peningkatan Pendapatan Mustahik Melalui Program Bangkit Usaha Mandiri Sukabumi (BUMI). Jati: Jurnal Akuntansi Terapan Indonesia, 2(2), 41-47.

\section{PENDAHULUAN}

Kemiskinan seringkali dianggap sebagai bagian yang tak terpisahkan dalam kehidupan. Beberapa penyebab kemiskinan, meliputi kemiskinan natural, kemiskinan kultural, dan kemiskinan struktural. Perhatian khusus harus diberikan kepada setiap elemen masyarakat yang belum berpenghidupan layak. Penanggulangan kemiskinan dapat melalui 
optimalisasi dana zakat, infak, dan sedekah (ZIS). ZIS merupakan salah satu komponen dalam kesejahteraan Islam. Apabila ZIS dikelola sebagaimana dicontohkan oleh Nabi Muhammad SAW, niscaya mampu meningkatkan kesejhteraan masyarakat, mengurangi pengangguran, dan sekaligus mengurangi jumlah kaum fakir miskin.

Fungsi ZIS untuk memberdayakan ekonomi masyarakat ini semakin dibutuhkan, mengingat jumlah penduduk miskin di kabupaten Sukabumi tergolong tinggi. Badan Pusat Statistik (BPS) kabupaten Sukabumi menunjukkan bahwa sekitar 197.120 penduduk di kabupaten Sukabumi berada dalam kategori miskin. Jumlah tersebut setara dengan 8,04\% dari total jumlah penduduk di kabupaten Sukabumi yang kurang lebih sebanyak 2.453.498 jiwa. Dan dalam kurun waktu tahun 20132017 persentase jumlah penduduk miskin di kabupaten Sukabumi telah mengalami penurunan. Namun, meskipun begitu jumlahnya masih tergolong tinggi.

ZIS dapat berfungsi sebagai salah satu sumber dana sosial-ekonomi bagi umat Islam. Artinya, pendayagunaan ZIS yang dikelola tidak hanya sebatas pada kegiatan sosial tertentu saja, tetapi dapat pula dimanfaatkan untuk kegiatankegiatan ekonomi umat, seperti dalam program pengentasan kemiskinan dan pengangguran dengan memberikan zakat produktif kepada mustahik yang memerlukan sebagai modal usaha.

Untuk memaksimalkan potensi zakat dalam upaya meningkatkan kesejahteraan masyarakat, pendayagunaan zakat sekarang ini dilakukan dengan dua cara yaitu pendayagunaan zakat secara konsumtif dan produktif. Zakat yang bersifat konsumtif adalah zakat yang diberikan hanya satu kali atau sesaat saja (digunakan hanya sekali). Sedangkan zakat yang bersifat produktif adalah zakat yang lebih diprioritaskan untuk usaha yang produktif. Zakat produktif dapat diberikan apabila kebutuhan mustahik sudah terpenuhi dan terdapat kelebihan.

Dana ZIS yang diberikan dalam bentuk permodalan akan sangat membantu kegiatan ekonomi masyarakat dan mengembangkan usahausaha golongan ekonomi lemah. Dengan kata lain, dana ZIS yang diberikan kepada mustahik tidak langsung dihabiskan, tetapi dikembangkan dan digunakan untuk membantu usaha mereka, sehingga dengan usaha tersebut mereka dapat memenuhi kebutuhan hidup secara terus-menerus.

Pengembangan zakat bersifat produktif dengan cara dijadikannya dana infak dan sedekah sebagai modal usaha, untuk pemberdayaan ekonomi penerimanya dan supaya fakir miskin dapat menjalankan atau membiayai kehidupan secara konsisten. Dengan dana zakat tersebut fakir miskin akan mendapatkan penghasilan tetap, mengembangkan usaha serta mereka dapat menyisihkan penghasilannya untuk menabung.

Saat ini pendayagunaan zakat secara produktif sedang mengalami kemajuan pesat, karena dari pengelolaan zakat secara produktif mampu memberikan hasil yang lebih optimal untuk meningkatkan kesejahteraan masyarakat. Salah satu organisasi yang menerapkan pendayagunaan zakat produktif adalah Badan Amil Zakat Nasional (BAZNAS) Kabupaten Sukabumi. Setiap tahunnya, BAZNAS Kabupaten Sukabumi terus meningkatkan kinerjanya, baik dalam penghimpunan zakat, infak, dan sedekah maupun dalam pendayagunaan ZIS tersebut. Terutama dalam mengelola zakat produktif dengan program-program yang mengedepankan pemberdayaan masyarakat.

Badan Amil Zakat Nasional Kabupaten Sukabumi menyalurkan dana zakat produktif program Sukabumi Sejahtera yaitu Bangkit Usaha Mandiri Sukabumi Berbasis Masjid Desa Peradaban Zakat (BUMI-DPZ). Dengan memberikan bantuan modal usaha yang disalurkan untuk pemberdayaan ekonomi masyarakat berbasis kelompok dan diberikan pengetahuan dan keterampilan dalam pemasaran produk usaha mikro. Secara keseluruhan penerima manfaat pada program BUMI-DPZ dari tahun 2016-2018 ini sebanyak 950 keluarga dari 38 KSM (Kelompok Swadaya Masyarakat) yang tersebar di 23 Kecamatan di Kabupaten Sukabumi (Kalapanunggal, Cibadak, Cisaat, Nagrak, Nyalindung, Purabaya, Jampang Tengah, Sukaraja, Cikakak, Jampang Kulon, Kabandungan, Caringin, Kadudampit, Sukabumi, Gegerbitung, Surade, Sagaranten, Cidolog, Tegal Buleud). Dengan bantuan modal usaha yang diberikan BAZNAS Kabupaten Sukabumi, mustahik dapat mengembangkan usaha mereka dan bisa meningkatkan pendapatan mereka.

Namun dalam pendayagunaan dana zakat produktif belum sepenuhnya efektif, karena dana zakat tersebut selain digunakan untuk usaha, mustahik juga menggunakan dana zakatnya untuk dikonsumsi. Mustahik mengalami beberapa permasalahan baru yang menyebabkan terjadinya perbedaan jumlah pendapatan mustahik. Kenyataannya lebih kepada usaha yang memiliki kondisi tetap, meskipun ada usaha mustahik yang memiliki pendapatan yang baik dan maju. Seperti terlihat dalam tabel 1.

Berdasarkan tabel 1, kondisi kesejahteraan mustahik sejatinya lebih kepada pendapatan yang tetap, karena dari tahun 2015 sampai dengan tahun 
Tabel 1. Perubahan Pendapatan Mustahik Setelah Diberi Dana Zakat Produktif Tahun 2015-2018

\begin{tabular}{cccc}
\hline \multirow{2}{*}{ Tahun } & \multicolumn{3}{c}{$\begin{array}{c}\text { Kesejahteraan Mustahik/ } \\
\text { Pendapatan Mustahik }\end{array}$} \\
\cline { 2 - 4 } & Tetap & Membaik & Maju \\
\hline 2015 & $39 \%$ & $29 \%$ & $32 \%$ \\
\hline 2016 & $50 \%$ & $30 \%$ & $20 \%$ \\
\hline 2017 & $50 \%$ & $20 \%$ & $30 \%$ \\
\hline 2018 & $50 \%$ & $30 \%$ & $20 \%$ \\
\hline Sumber: Laporan Perkembangan Usaha Mustahik, BAZNAS Kabupaten Sukabumi
\end{tabular}

2018 rata-rata pendapatan mustahik sebagian besar kepada usaha yang berpendapatan tetap, adapun pendapatan mustahik yang membaik dan maju mengalami fluktuatif dan lebih kecil dari pendapatan mustahik dalam kondisi tetap. Peneliti tertarik untuk mengetahui lebih dalam apakah program pendayagunaan zakat produktif yang dikelola BAZNAS dapat berdaya guna dalam upaya peningkatan pendapatan para mustahik di Kabupaten Sukabumi.

Berdasarkan pada uraian di atas, maka dapat dirumuskan masalah sebagai berikut:

1. Bagaimana pendayagunaan zakat produktif yang diterapkan oleh BAZNAS Kabupaten Sukabumi?

2. Bagaimana analisis pendayagunaan zakat produktif program BUMI dalam peningkatan pendapatan mustahik?

3. Bagaimana faktor pendukung dan penghambat dalam pendayagunaan zakat produktif program BUMI?

Berdasarkan rumusan masalah, maka tujuan dari penelitian ini adalah untuk mengetahui analisis pendayagunaan zakat produktif dalam peningkatan pendapatan mustahik melalui program bangkit usaha mandiri sukabumi (BUMI).

Penelitian terdahulu diantaranya, menganalisis dampak dari pemberian zakat produktif dalam bentuk modal usaha oleh Baitul Mal Kabupaten Aceh Utara kepada masyarakat miskin dalam upaya pegentasan kemiskinan di Kabupaten Aceh Utara. Untuk keperluan analisis data dipergunakan data primer hasil penelitian lapangan yang berbentuk "Cross section data". Data yang diambil adalah tentang modal dan pendapatan sebelum dan sesudah mendapatkan zakat produktif dalam bentuk modal usaha. Sampel yang diambil adalah 77 orang dari 10 kecamatan yang ada di Kabupaten Aceh Utara. Model yang digunakan dalam penelitian ini adalah persamaan regresi linear dan untuk analisis data digunakan analisis uji beda wilcoxon. Hasil penelitian mengungkapkan bahwa pemberian modal zakat produktif dalam bentuk modal usaha berdampak positif dan dapat menurunkan angka. (Rusli, Hamzah, \& Syahnur, 2013).
Penelitian yang dilakukan di LAZ (Lembaga Amail Zakat) Yayasan Solo Peduli Surakarta. LAZ Yayasan Solo Peduli Surakarta merupakan salah satu LAZ terbesar di Surakarta. Masalah utama dari penelitian ini adalah pengaruh dana zakat produktif terhadap mustahiq. Desain penelitian adalah kuantitatif dan analisisnya adalah statistik dengan menggunakan regresi sederhana. Hasil penelitian ini mengungkapkan bahwa dana zakat produktif untuk tahun 2007 berpengaruh terhadap pendapatan mustahiq secara signifikan. Tingkat signifikan atau nilainya mencapai 0,045 atau sig <0,05. Dengan kata lain ada korelasi positif antara dana zakat produktif dengan pendapatan mustahiq (Sartika, 2008).

Penelitian lain yang berkaitan dengan zakat produktif adalah penelitian dari Toriquddin (2015). Praktek distribusi harta zakat di Rumah Zakat melalui program Senyum Mandiri dengan cara diproduktifkan sudah sesuai dengan maqashid al syariah. Hakikat maqashid al syariah Ibnu 'Asyur adalah bagaimana suatu hukum memberikan kemanfaatan secara kulliy (menyeluruh) bagi umat manusia. Selanjutnya alasan pengelolaan zakat produktif di Rumah Zakat adalah untuk memberi rahmat bagi mustahiq secara khusus dan umat Islam secara umum. Tujuan menjadi 'amil zakat adalah dalam rangka beribadah kepada Allah, karena jabatan adalah amanah maka pengurus Rumah Zakat berusaha sebaik- baiknya menjalankan tugas dengan berinovasi memproduktifkan harta zakat. Hal ini sesuai dengan maqashid al Syariah (Toriquddin, 2015).

\section{METODE PENELITIAN}

Penelitian ini menggunakan metode kualitatif dan dengan jenis pendekatan deskriptif. Dengan tujuan untuk membuat deskripsi, gambaran atau lukisan secara sistematis, faktual dan akurat mengenai fakta-fakta di lapangan.

Teknik pengambilan subjek menggunakan teknik sampling purposive adalah teknik penentuan sampel dengan pertimbangan tertentu seperti menggunakan sumber data dari orang yang ahli atau memahami variabel yang sedang kita teliti. 
Dalam penelitian kualitatif sampel sumber data yang dikemukakan masih bersifat sementara. (Sugiyono, 2016) Subjek dalam penelitian ini yaitu ketua BAZNAS Kabupaten Sukabumi, kadiv bidang pengumpul, dan mustahik penerima zakat produktif. Adapun objek penelitiannya pendayagunaan zakat produktif dalam peningkatan pendapatan mustahik melalui program Bangkit Usaha Mandiri Sukabumi (BUMI).

Teknik pengumpulan data menggunakan metode observasi lapangan, wawancara, dokumentasi, dan triangulasi. Teknik analisis data menggunakan model Miles and Huberman. (Sugiyono, 2016) menggunakan tahap-tahap yang dimulai dari pengumpulan data, reduksi data, penyajian data, dan penarikan kesimpulan.

\section{HASIL DAN PEMBAHASAN}

\section{Gambaran Umum Program Bangkit Usaha Mandiri Sukabumi (BUMI)}

Program BUMI-DPZ merupakan salah satu program pendayagunaan dana zakat, infak dan sedekah (ZIS) yang bertujuan membangun keimanan dan ketaqwaan mustahik berupa pemberian modal usaha melalui dana bergulir di wilayah program pemberdayaan mustahik BAZNAS Kabupaten Sukabumi. Pada saat yang bersamaan mendorong peningkatan pendapatan mustahik melalui pendampingan usaha, pembinaan rutin, dan monitoring aktivitas ibadah dengan perkuatan pendanaan usaha jamaah masjid.

Sasaran yang menjadi anggota BUMI yaitu mustahik (fakir/miskin) dan tinggal disekitar masjid di wilayah yang sudah dipilih oleh BAZNAS Kabupaten Sukabumi. Hal tersebut karena sumber dana yang digunakan untuk program ini adalah dana zakat. Kriteria fakir merujuk pada ketentuan bahwa seseorang yang memiliki harta atau usaha yang kurang dari seperdua kebutuhannya dan jika penghasilannya berjumlah dibawah Rp 400.000,00. Sedangkan kriteria miskin adalah seseorang yang memiliki harta atau usaha yang kurang dari setengah kebutuhannya dan jika jika penghasilannya berjumlah dibawah Rp 600.000,00.

Dalam pemberian bantuan modal kerja, ada kriteria khusus yang harus dilihat. Jadi sebelum dana diberikan harus ada survey kepada calon penerima dana zakat produktif. Kriteria usaha yang akan dibantu, dengan ketentuan: Mempunyai usaha yang dijalankan (skala usaha kecil), Berdomisili di tempat program digulirkan (kampung/ dusun/ desa/ kelurahan) di mana program dilaksanakan minimal sudah 2 (dua) tahun, Berusia antara 20 s.d. 60 tahun (usia produktif), Sudah menikah / pernah menikah (duda/janda), dan Berpenghasilan kurang dari 2,5 juta / bulan.

Sistematika penyaluran zakat produktif dilakukan oleh BAZNAS Kabupaten Sukabumi dan akan disalurkan ke beberapa daerah di Kabupaten Sukabumi melalui pendamping yang sudah dipilih oleh BAZNAS kabupaten Sukabumi.

Pendistribusian Zakat Produktif Melalui Program Bangkit Usaha Mandiri Sukabumi (BUMI) di BAZNAS Kabupaten Sukabumi

Pendistribusian zakat produktif di Kabupaten Sukabumi dilaksanakan berdasarkan syarat dan ketentuan umum yang sudah diterapkan di BAZNAS Kabupaten Sukabumi. Dalam proses penyaluran zakat produktif hingga dana tersebut sampai di tangan mustahik, BAZNAS Kabupaten Sukabumi membutuhkan bantuan dari berbagai pihak dan harus melakukan beberapa tahapan terlebih dahulu. Gambar 1 menunjukkan beberapa tahapan dalam mendistribusikan zakat produktif melalui program BUMI di BAZNAS Kabupaten Sukabumi.

Langkah awal yang dilakukan pihak BAZNAS Kabupaten Sukabumi adalah mencari masjid yang berkenan menjadi mitra dalam menjalankan program BUMI. Setelah pengurus masjid menyetujui kerja sama untuk menjadi mitra BAZNAS, selanjutnya pengurus masjid harus merekomendasikan kelompok/mustahik yang layak untuk menerima bantuan zakat produktif. Jika kelompok/mustahik yang diajukan masjid layak untuk menerima zakat produktif maka BAZNAS akan memilih pendamping yang akan menjalankan program BUMI. Pendamping adalah seseorang yang memiliki jiwa sosial tinggi dari semua profesi yang memiliki waktu luang disela-sela kegiatannya dan memiliki tanggung jawab yang besar untuk menjadi pelaksana, pengontrol, dan pemegang amanah atas terlaksana program BUMI.

Pembentukan kelompok BUMI, pada setiap masjid terdapat 25 anggota dan masing-masing diberikan modal bergulir dengan akad qard sebesar Rp 1.000.000, modal yang diberikan akan diangsur setiap pekan, untuk jumlah angsuran ditentukan oleh BAZNAS dengan batasan waktu maksimal 40 minggu/10 bulan. Seiring dengan berjalannya program, akan diadakan pertemuan rutin setiap minggu untuk pembayaran angsuran. Selain itu pendamping juga mengadakan pengontrolan usaha, dengan mengadakan kajian dan sharing dengan anggota dalam menjalankan masing-masing usaha. Selain pengontrolan usaha pendamping melakukan pengontrolan ibadah mustahik dalam mengaji.

Setelah semua kegiatan sudah dilakukan, pihak pendamping akan membuat laporan bulanan terkait pembayaran angsuran anggota, peningkatan usaha, ibadah anggota, dan keadaan anggota ke- 


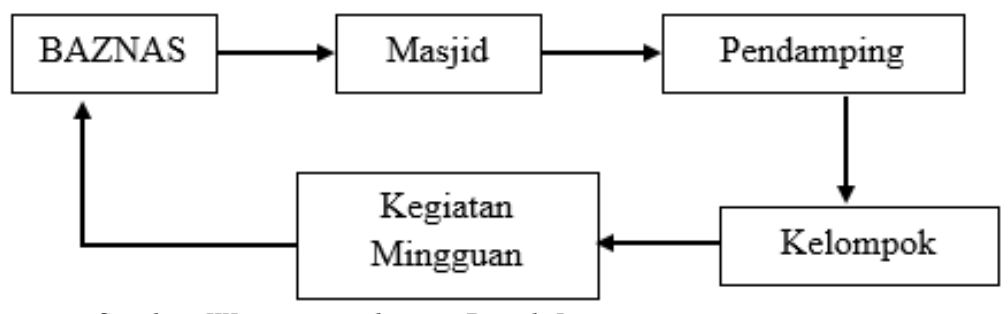

Sumber: Wawancara dengan Bapak Iyan

Gambar 1. Sistematika Pendistribusian Zakat Produktif Program BUMI di BAZNAS Kabupaten Sukabumi

lompok apakah ada yang macet dalam pembayaran. Serta semua masalah yang dialami di lapangan. laporan tersebut diberikan kepada pihak BAZNAS sebagai laporan pertanggungjawaban serta bentuk evaluasi untuk bulan selanjutnya. Program BUMI yang dilaksanakan di Kabupaten Sukabumi dilakukan pada 37 masjid. Dari 37 masjid tersebut, sebagian besar masjid sudah tidak aktif dalam menjalankan program BUMI.

Pendayagunaan Zakat Produktif yang diterapkan oleh Badan Amil Zakat Nasional Kabupaten Sukabumi Melalui Program BUMI

Dalam pendayagunaan dana zakat produktif di Kabupaten Sukabumi dilakukan dengan cara pembagian dana produktif kreatif, yaitu memberikan modal bergulir kepada anggota untuk dikelola sendiri dalam mengembangkan usahanya. Tujuan peyaluran dana zakat produktif ini adalah untuk pemberdayaan masyarakat terutamanya dalam peningkatan pendapatan, sehingga terwujudnya masyarakat maju, sejahtera, dan mubarokah.

Proses pendayagunaan dana zakat produktif program BUMI di Kabupaten Sukabumi dapat dianalisis dalam tiga tahap, yaitu sebelum zakat produktif diterima oleh mustahik, pada saat zakat produktif sudah diterima oleh mustahik, dan setelah zakat produktif diterima oleh mustahik.

Ada beberapa tahapan yang harus dilakukan sebelum zakat produktif disalurkan kepada mustahik yaitu penyaluran dana dari muzakki yang diberikan kepada amil. Selanjutnya dalam mencari mustahik produktif, pada penerapannya pendamping mensosialisasikan terlebih dahulu kepada tokoh ulama di masjid tersebut dan kepada masyarakat sekitar. Kemudian masyarakat (kelompok majlis taklim/UPZ) mengajukan dengan menyiapkan anggota, jenis usaha, tempat/lokasi mustahik dan syarat terlampir. Setelah semuanya persyaratan terpenuhi BAZNAS akan menyurver kelayakan kelompok jika layak maka BAZNAS akan menyiapkan pendamping untuk mendampingi kelompok tersebut.

Setelah menetapkan mustahik yang layak untuk menerima zakat produktif program BUMI, selanjutnya ada kegiatan-kegiatan yang dilakukan di dalam kelompok yaitu kegiatan pengontrolan usaha, pengontrolan ibadah, kegiatan rutin mingguan, dan pembayaran angsuran. Setelah zakat produktif diterima oleh mustahik, selanjutnya adalah tugas pendamping untuk melaporkan semua kegiatan yang sudah dilakukan oleh pendamping, pelaporan ini dilakukan setiap satu minggu sekali yang berisi mengenai, kegiatan kelompok, ibadah anggota, dan angsuran anggota. Laporan tersebut dijadikan pihak BAZNAS sebagai pertanggung jawaban program dan evaluasi pada pendayagunaan zakat produktif selanjutnya.

\section{Analisis pendayagunaan zakat produktif dalam peningkatan pendapatan mustahik melalui pro- gram BUMI-DPZ}

Dengan adanya bantuan pemberian zakat produktif berupa dana bergulir ini, beberapa anggota mengalami peningkatan pendapatan usaha meskipun tidak banyak. Namun para anggota sudah merasa bersyukur karena sudah dapat memenuhi kebutuhan dan dapat membayar iuran setiap minggu. Peningkatan pendapatan ini dapat terrealisasi karena beberapa hal, yaitu sebagai berikut: peningkatan produk yang dijual/ diproduksi, perbaikan sarana fisik, perluasan Usaha, dan peningkatan jumlah pelanggan

Pemberian dana zakat produktif ini sudah mampu memberikan manfaat dalam peningkatan pendapatan mustahik. Namun, peningkatan keuntungan dalam usaha semua anggota tidak dapat memperkirakan karena jenis usaha dagang dengan keuntungan harian sehingga tergantung ramai atau tidak dalam berjualan. Oleh sebab itu sulit untuk menyebutkan berapa peningkatan keuntungan usaha anggota. Sama halnya ketika para anggota ditanya awal modal saat membuka usaha, karena semua usaha sudah dijalankan cukup lama sehingga jumlah modal beberapa tahun yang lalu tidak bisa dibandingkan dengan jumlah modal jika usaha didirikan sekarang. Ada juga anggota yang tidak berhasil dalam mengelola zakat produktif itu dan 
tidak dapat meningkatkan pendapatannya dikarenakan dana zakat itu digunakan untuk memenuhi kebutuhan sehari-hari, membayar hutang ke rentenir, atau digunakan untuk membayar pendidikan anak-anaknya.

Faktor Pendukung dan Penghambat dalam Pendayagunaan Zakat Produktif melalui Program BUMI

Setiap organisasi pasti memiliki faktor pendukung dan penghambat dalam pelaksanaan program-program yang telah direncanakan. Dari hasil penelitian pada Badan Amil Zakat kabupaten Sukabumi ditemukan adanya faktor pendukung dalam pendayagunaan zakat produktif melalui program BUMI. Pertama, adanya dukungan dari tokoh ulama dan masyarakat sekitar kelompok binaan yang membantu dalam merekomendasikan dan proses pendataan. Kedua, niat kuat mustahik untuk menjadi muzakki. Ketiga, adanya kerjasama yang baik antara BAZNAS kabupaten Sukabumi dan mustahik dalam menyampaikan laporan perkembangan usahanya baik secara lisan maupun tulisan.

Selain faktor pendukung BAZNAS kabupaten Sukabumi menghadapi beberapa kendala atau terdapat faktor penghambat sehingga seringkali pendayagunaan zakat produktif melalui program BUMI masih belum optimal. Pertama, pendamping menggunakan manajemen Lillahhi Ta'ala sehingga lebih sering pasrah dan dalam memberikan motivasi masih bersifat santai. Kedua, adanya keterbatasan alokasi dana yang diberikan untuk program pendayagunaan zakat produktif. Ketiga, kondisi mentalitas mustahik. Sebenarnya ketiga faktor inilah yang harus dipecahkan secara bersama-sama oleh setiap elemen dalam pendayagunaan zakat produktif, sebab tanpa kerjasama aktif antar institusi baik dari swasta maupun pemerintah hambatan-hambatan ini tidak akan dapat terselesaikan.

\section{SIMPULAN}

Berdasarkan penelitian yang telah dilakukan oleh penulis mengenai Analisis Pendayagunaan Zakat Produktif dalam Peningkatan Pendapatan Mustahik melalui Program Bangkit Usaha Mandiri Sukabumi di Badan Amil Zakat Nasional Kabuapaten Sukabumi, maka dapat dikemukakan simpulan sebagai berikut:

Dalam proses pendayagunaan zakat produktif program BUMI di Kabupaten Sukabumi pada dasarnya sudah sesuai dengan prosedur pendayagunaan zakat produktif, namun secara praktiknya masih banyak kekurangan yang disebabkan karena terbatasnya kemampuan pihak BAZNAS kabupaten Sukabumi dalam pengontrolan dan pihak pendamping dalam menjalankan tanggungjawab. Serta situasi yang berbeda antara konsep yang sudah direncanakan oleh pihak BAZNAS dengan keadaan yang sebenarnya terjadi di lapangan.

Pemberian zakat produktif ini sudah mampu memberikan manfaat dalam keberhasilan usaha mustahik. Dapat dilihat dari terpenuhinya modal anggota setelah menerima zakat produktif yang digunakan sebagian besar anggota untuk menambah jumlah produksi, sehingga dapat menambah pendapatan. Selain manfaat dalam peningkatan pendapatan yang berupa materi, kegiatan yang dilakukan oleh program BUMI ini juga dapat menumbuhkan keuntungan non materi kepada internal perorangan dalam bentuk meningkatkan keimanan dan eksternal seperti terciptanya suasana persaudaraan dan kepedulian sosial.

Faktor pendukung dalam pendayagunaan zakat produktif adalah adanya dukungan dari tokoh ulama dan masyarakat sekitar kelompok binaan, niat kuat mustahik untuk menjadi muzakki dan adanya kerjasama yang baik antara BAZNAS kabupaten Sukabumi dan mustahik dalam menyampaikan laporan perkembangan usaha. Sedangkan untuk faktor penghambatnya yaitu, pendamping menggunakan manajemen Lillahhi Ta'ala dan kurangnya waktu pendamping, adanya keter-batasan alokasi dana yang diberikan untuk program pendayagunaan zakat produktif, dan kondisi mentalitas mustahik menjadi faktor penghambat utama.

Saran ini ditujukan penulis kepada Badan Amil Zakat (BAZNAS) Kabupaten Sukabumi, sebagai bentuk kepedulian dengan memberi masukan agar program pendayagunaan zakat produktif dapat lebih baik lagi kedepannya. Terutama dalam pendayagunaan zakat produktif program Bangkit Usaha Mandiri Sukabumi (BUMI). Beberapa saran dari penulis yaitu: pertama, Kedepannya BAZNAS Kabupaten Sukabumi harus memberikan gaji yang layak untuk pendamping supaya pendamping lebih bersemangat dan bertanggungjawab dalam melaksanakan tugasnya sehingga dapat memaksimalkan dalam proses pendampingan dan pengontrolan usaha mustahik. Kedua, Pihak BAZNAS Kabupaten Sukabumi harus memberikan pelatihan- pelatihan seperti seminar wirausaha dan pelatihan softskill kepada mustahik agar mereka tidak salah menggunakan dana zakat produktif yang dipinjamkan. Ketiga Menambah alokasi dana untuk program pemberdayaan ekonomi yang bersifat produktif, agar para mustahik kedepannya bisa menjadi muzakki. 


\section{DAFTAR PUSTAKA}

Andriyanto, I. (2011). Strategi Pengelolaan Zakat Dalam. Walisongo.

Dimyati, D. (2018). Urgensi Zakat Produktif di Indonesia. Al-Tijary. https://doi.org/10.21093/at.v2i2.693

Huda, N., \& Sawarjuwono, T. (2013). Akuntabilitas Pengelolaan Zakat melalui Pendekatan Modifikasi Action Research. Jurnal Akuntansi Multiparadigma. https://doi.org/10.18202/jamal.2013.12.7204

Kuncoro, A. T. (2017). Zakat: Katup Pengaman Keseimbangan Ekonomi Umat. Ulul Albab: Jurnal Studi Dan Penelitian Hukum Islam. https://doi.org/10.30659/jua.v1i1.2213

Mashudi, M. (2015). Urgensi Zakat Dalam Revolusi Mustahik Menjadi Muzakki. Iqtishoduna: Jurnal Ekonomi Islam.

Rusli, Hamzah, A., \& Syahnur, S. (2013). Analisis Dampak Pemberian Modal Zakat. Jurnal Ilmu Ekonomi Pascasarjana Universitas Syiah Kuala.

Saini, M. (2016). Pemberdayaan Ekonomi Ummat Melalui Zakat Produktif (Studi Kritik Atas Tata Kelola Badan Amil Zakat Nasional [BAZNAS] Kabupaten Nganjuk). Jurnal Lentera.

Sartika, M. (2008). Pengaruh Pendayagunaan Zakat Produktif terhadap Pemberdayaan Mustahiq pada LAZ Yayasan Solo Peduli Surakarta. La_Riba. https://doi.org/10.20885/lariba.vol2.iss1.art6

Sugiyono, P. D. metode penelitian kuantitatif, kualitatif,dan R\&D. , Alfabeta, cv. (2016).

Toriquddin, M. (2015). ZAKAT KOTA MALANG PERSPEKTIF MAQASHID AL SYARIAH IBNU' ASYUR. Ulul Albab.

Hanjani, A., \& Haryati, D. A. (2018). Mekanisme Pembiayaan Murabahah Pada Nasabah di Baitul Maal Wa Tamwil Universitas Muhammadiyah Yogyakarta. Jati: Jurnal Akuntansi Terapan Indonesia, 1(1), 46-51.

Badan Pusat Statistik (BPS) diakses dari https://sukabumikab.bps.go.id/, diakses pada tanggal 6 Mei 2019

Fadly, Isbir. 2012. Buku Panduan Zakat. [Online] Tersedia: http://jatim.kemenag.go.id/file/file/pdf/urev142 5010734.pdf

Hasan, Muhammad. 2011. Manajemen Zakat Model Pengelolaan yang Efektif. Yogyakarta. Idea Press Yogyakarta.

Nazir, Moh. 2014. Metode Penelitian. Bogor 